\title{
Nutraceutical potential, quality and sensory evaluation of camu-camu pure and mixed jelly
}

\author{
Maria L. GRIGIO ${ }^{1}$, Elias A. MOURA ${ }^{2 *}$ (D), Gabriella F. CARVALHO ${ }^{1}$, Jayne J. ZANCHETTA ${ }^{1}$, \\ Pollyana C. CHAGAS ${ }^{1}$, Edvan A. CHAGAS ${ }^{3}$, Maria Fernanda B. DURIGAN ${ }^{3}$
}

\begin{abstract}
The objective of this work was to formulate and to characterize chemically and physically different formulations of camu-camu jellies, with or without mixture of other fruits. Their sensory acceptance was evaluated by identifying the formulations with greater acceptability while maintaining their nutraceutical potential. The formulations were: camu-camu jelly, camu-camu jelly with jabuticaba, camu-camu jelly with guava, camu-camu jelly with acerola, camu-camu jelly with passion fruit and camu-camu jelly with papaya. Untrained tasters were used to assess consumer acceptability. In a second scale the purchase intention was evaluated. The following variables were also analyzed: $\mathrm{pH}$, soluble solids, titratable acidity, ratio (SS/TA), ascorbic acid, total anthocyanins and flavonoids, phenolic compounds and antioxidant activity by the DPPH and FRAP methods. The results showed that camu-camu jelly without mixtures was not well accepted in the sensory test when compared to the others. The greatest preference was for mixed jams of camu-camu with guava and jabuticaba, in which they obtained greater acceptance and purchase intention. Jellies with higher levels of bioactive compounds and antioxitant activity obtained low acceptance and purchase intention, perhaps due to their high astringency.
\end{abstract}

Keywords: antioxidants; acerola; caçari; jabuticaba; Myrciaria dubia.

Practical Application: Camu-camu jelly is rich in bioactive compounds, and the mixture of camu-camu with other fruits complements other jellies with the bioactive compounds present in camu-camu. In addition to being a viable means for preserving and maintaining these products for a longer time.

\section{Introduction}

Among the species of native Amazon fruit with promising potential are the Myrtaceae family, which belongs to the camu-camu (Myrciaria dubia (Kunth) Mc Vaugh), due to its great scientific, biotechnological, economic, nutritional and functional potential (Grigio et al., 2021). The increased economic exploitation of some fruit products and by-products is being attributed to growing consumer concern with healthy diet (Azevêdo et al., 2015; Fidelis et al., 2019; Yahia, 2009).

The growing interest in camu-camu fruits is mainly due to their remarkable vitamin $\mathrm{C}$ content of up to $7,355 \mathrm{mg} 100 \mathrm{~g} \mathrm{~g}^{-1}$ of fresh pulp (Chagas et al., 2015). Moreover, camu-camu fruits contain other antioxidant compounds such as carotenoids, anthocyanins and other phenolic compounds provided by their ingestion (Bataglion et al., 2015; Fracassetti et al., 2013; Fujita et al., 2015; Neves et al., 2015) with high antioxidant activity.

According to (Chirinos et al., 2010), the antioxidant capacity of camu-camu fruits is mainly due to vitamin $\mathrm{C}$, followed by the activity of phenolic compounds such as catechins and their derivatives, anthocyanins, flavanols and flavanones.

Due to concentrated production from January to March and the rapid loss of postharvest quality, the supply of fresh fruits to the market is limited. A viable alternative for the economic use of these fruits is industrialization as by-products (Azevêdo et al., 2014; Conceição et al., 2019; Fidelis et al., 2019; Grigio et al., 2019, 2021).

Thus, the development of camu-camu processing technologies is an alternative to increasing camu-camu lifespan and, in some cases, a solution to reducing transportation and storage costs, as well as adding value, enhancing family farming and food security.

Jellies are products that can be processed with easily accessible ingredients, using native fruit pulp from the Amazon region, enabling added value and improving the exploratory potential of camu-camu. However, due to the variability of formulations and interactions between the ingredients used, besides the technological evaluation, sensory evaluation is necessary to obtain more information about the potential of the resulting products. Whereas the use of descriptive sensory methods with consumers provides valid and reliable information on the sensory characteristics of food products (Costa et al., 2020).

Mixed jellies combine characteristics of two or more fruits, allowing products with higher nutritional value and pleasant sensory properties, adding value and creating possibilities to gain more space in the consumer market (Viana et al., 2012). Some scientific work has already been developed in this sense, 
mixing two or more fruits to obtain a higher nutritional value with Araújo et al. (2014) pepper $\mathrm{x}$ acerola (Capsicum chinense x Malpighia emarginata) and Ferreira et al. (2011) watermelon $\mathrm{x}$ tamarind (Citrullus lanatus $\mathrm{x}$ Tamarindus indica $\mathrm{L}$.).

The huge variety of fruits produced in Brazil allows combining flavors to make mixed jellies, with the use of already familiar fruits, such as papaya (Carica papaya), passion fruit (Passiflora edulis), acerola (Malpighia emarginata), jabuticaba (Myrciaria jaboticaba), guava (Psidium guajava L), and potential but still little known fruits, such as camu-camu. In this case, the mixture of materials in the confection of jellies has the purpose of exploring bio compounds present in camu-camu, mixing it with other fruits that are popular, transforming the already marketed jellies into products with greater nutraceutical and functional potential.

In the present work, because we are studying a fruit known for its high acidity, we chose to prepare mixed formulations in order to minimize excessive acidity. Thus, the objective of this work was to formulate and to characterize chemically and physically the different formulations of camu-camu jellies with and without mixing with other fruits (mixed), evaluating its acceptance through sensory tests, as well as the maintenance of organoleptic properties and nutraceutical potential after processing.

\section{Material and methods}

\subsection{Experimental characterization}

To carry out the experiment, camu-camu fruits were harvested at a mature stadium in the Embrapa experimental area located in the Serra da Prata experimental field, in the municipality of Mucajaí-Roraima, Brazil.

After harvesting, the fruits were taken to Embrapa-RR Post Harvest Laboratory, where they were cleaned and evaluated for the absence of damage, washed in running water and sanitized with $0.02 \%$ sodium hypochlorite $(\mathrm{NaClO})$ for 30 minutes. After cleaning the fruits were properly pulped in an industrial pulping machine without water, where the pulp was separated from the shells and seeds. For the treatments we used camu-camu pulp and jabuticaba, papaya, guava, acerola and passion fruit pulp obtained from the local market in Boa Vista-Roraima, Brazil.

\subsection{Experimental design}

The experimental trial was conducted with the following treatments: Pure camu-camu jelly (51\% camu-camu pulp; $49 \%$ sugar and 0.005 pectin); Camu-camu jelly with jabuticaba (38.5\% camu-camu pulp; $12.5 \%$ jabuticaba pulp; $49 \%$ sugar and 0.005 pectin); Camu-camu jelly with guava ( $38.5 \%$ camu-camu pulp; $12.5 \%$ guava pulp; $49 \%$ sugar and 0.005 pectin); Acerola camucamu jelly (38.5\% camu-camu pulp; $12.5 \%$ acerola pulp; $49 \%$ sugar and 0.005 pectin); Camu-camu jelly with passion fruit (38.5\% camu-camu pulp; $12.5 \%$ passion fruit pulp; $49 \%$ sugar and 0.005 pectin); Camu-camu jelly with papaya ( $38.5 \%$ camucamu pulp; $12.5 \%$ papaya pulp; $49 \%$ sugar and 0.005 pectin);
The experiment was fully randomized with treatments consisting of six different formulations of pure or mixed camucamu jelly, and each treatment consisted of four replications.

Jellies were made following the composition of each treatment detailed above. The material was brought to medium heat of $100^{\circ} \mathrm{C}$, cooking until reaching the point of jelly. The obtained jelly was placed in sterile glass jars, still hot. These vials were immediately sealed and stored at room temperature, approximately $25^{\circ} \mathrm{C}$.

\subsection{Sensory analysis}

Sensory analysis: This study was duly registered and approved by the Research Ethics Committee of the Federal University of Roraima, under number 39610114.0.0000.5302, and the sensory analyzes performed at Embrapa Roraima, with the participation of 40 untrained tasters. The samples were placed in disposable cups and coded with random numbers. Each appraiser received all six jelly formulations and one sheet containing a questionnaire and a hedonic scale to evaluate appearance, color, taste and texture ranging from 9 to 1 (9- Liked it extremely, 8- Liked it a lot, 7- Liked it, 6-Somewhat liked it, 5- Indifferent, neither liked nor disliked, 4-Somewhat disliked, 3- Disliked, 2- Disliked moderately and 1- Disliked extremely), and another scale to gauge purchase intent previously reported Delgado-Nieblas et al. (2018) (1- Definitely would buy, 2- Probably would buy, 3- Maybe yes/maybe no, 4- Probably wouldn't buy, 5- Definitely wouldn't buy). Between evaluations, the evaluators drank water so that there was no interference between the formulations analyzed.

To calculate the Product Acceptability Index, we used the expression IA $(\%)=\mathrm{A} \times 100 / \mathrm{B}$, where, $\mathrm{A}=$ average grade obtained for the product and $\mathrm{B}=$ maximum grade given to the product. Usually the acceptability index is considered to have good repercussion when $\geq 70 \%$ (Dutcosky, 1996).

\subsection{Physico-chemical characteristics and bioactive compounds}

$\mathrm{pH}$ (hydrogen potential): carried out according to the methodology by Association of Official Analytical Chemists (2012), to determine the $\mathrm{pH}$, quantified by immersing the $\mathrm{pH}$ meter directly in the formulations.

Soluble Solids (SS): determined by refractometry, with portable refractometer, SOLOESTE brand, model RT-30ATC, with automatic temperature compensation $\left(10\right.$ to $\left.30^{\circ} \mathrm{C}\right)$ and results expressed in ${ }^{\circ}$ Brix (Association of Official Analytical Chemists, 2012).

Titratable acidity (TA): using methodology described by Association of Official Analytical Chemists (2012),weighing $10 \mathrm{~g}$ of each formulation, which were diluted in $100 \mathrm{~mL}$ of distilled water. For reading, after addition of the phenolphthalein indicator, the solution was titrated with $0.1 \mathrm{M} \mathrm{NaOH}$ solution. Results were expressed in mg citric acid per $100 \mathrm{~g}^{-1}$ sample.

Ratio: the ratio between the quantities of SS and TA.

Ascorbic acid: performed by extraction with $0.5 \%$ oxalic acid and titration with 2,6-dichlorophenolindophenol (Ranganna, 1986). 
Antioxidant activity (FRAP): The antioxidant capacity of each sample was estimated by the iron reduction method (FRAP), following a procedure adapted by (Rufino et al., 2006). About $1 \mathrm{~g}$ of sample added with $40 \mathrm{~mL}$ of $50 \%$ methanol was used, homogenized and allowed to stand for 60 minutes at room temperature. After this period the samples were centrifuged $(25.406,55 \mathrm{~g})$ for 15 minutes and the supernatant transferred to a $100 \mathrm{~mL}$ volumetric flask. To the residue of the first extraction $40 \mathrm{~mL}$ of $70 \%$ acetone was added, homogenized and allowed to stand for 60 minutes at room temperature. After one hour the samples were centrifuged again $(25.406,55 \mathrm{~g})$ for 15 minutes, and the supernatant transferred to the volumetric flask containing the first supernatant and the volume completed with distilled water. The obtained extract, added from the FRAP reagent, was taken to a warm water bath at $37^{\circ} \mathrm{C}$. The absorbance reading of the samples was taken at $595 \mathrm{~nm}$, and the results expressed in $\mathrm{mg}$ of ferrous sulfate $\mathrm{g}^{-1}$ sample.

Antioxidant activity (DPPH): The antioxidant activity can be determined in terms of oxidation inhibition potential by using the 2,2-diphenyl-1-picrilidrazil (DPPH) radical as a reference (Brand-Williams et al., 1995). 1 gram of the sample was weighed, then $10 \mathrm{ml}$ of ethyl alcohol were added, homogenized and centrifuged $(6000 \mathrm{rpm})$ for 50 minutes. After this period, the supernatant was removed by pipette and the solution was placed in a dark flask in an ice bath, which was added with $3 \mathrm{~mL}$ of ethanol. In a spectrophotometer at $517 \mathrm{~nm}$, the absorbance was measured at $500 \mu \mathrm{L}$ of the sample extract added with $300 \mu \mathrm{L}$ of the DPPH solution. Results were expressed as $\mu \mathrm{g}$ of ascorbic acid equivalent $\mathrm{g}^{-1}$ sample.

Total phenolic: Determination of the phenolic compound content was performed according to the Folin-Ciocalteu spectrophotometric method described by (Singleton et al., 1999). An aliquot of $20 \mu \mathrm{L}$ of sample was diluted to read $1.58 \mathrm{~mL}$ of water, then added $100 \mathrm{~mL}$ of Folin-Ciocalteu reagent and homogenized. Between $30 \mathrm{sec}$ and $8 \mathrm{~min} 300 \mu \mathrm{L}$ of the sodium carbonate solution was added and homogenized again. The solutions were left at $20^{\circ} \mathrm{C}$ for 2 hours and the absorbance of each solution determined at $765 \mathrm{~nm}$. Results were expressed as $\mathrm{mg}$ of $\mathrm{g}^{-1}$ gallic acid in the sample.

Total flavonoid content: determined by the aluminum chloride colorimetric assay (Zhishen et al., 1999) using quercetin as standard. To extract, methanol solution and 5\% aluminum chloride were added. After 30 minutes, spectrophotometer readings at $441 \mathrm{~nm}$ were taken. For each sample a blank was made containing added methanol sample. Results were expressed in $\mu \mathrm{g}$ quercetin equivalent $\mathrm{g}^{-1}$ sample.

Total anthocyanins: performed according to the method described by Lees \& Francis (1972), using cyanidin as standard. Samples were added to an acidified methanol solution $(\mathrm{HCl}$ (85:15)) and, after homogenization, the samples were stored in the dark. After storage for $24 \mathrm{~h}$, samples were read in a spectrophotometer at $520 \mathrm{~nm}$. Results were expressed as $\mu \mathrm{g}$ cyanidin equivalent $\mathrm{g}^{-1}$ sample.

\subsection{Statistical analysis}

The statistical analysis of data was expressed as the mean \pm standard deviation. Analyses of variance (ANOVA) were performed by the $\mathrm{F}(\mathrm{p}<0.01)$. The comparison of means was performed according to the least significant difference (LSD) test $(p<0.05)$. The relationship between the evaluated parameters of the different jelly formulations was estimated considering Pearson's correlation coefficient $(\mathrm{p}<0.05)$. The variables were subjected to multivariate analysis. The multivariate analysis of the data was performed by principal component analysis (PC), in order to better show the distribution of different jelly formulations and the purchase intention of products with sensory characteristics, organoleptic quality and bioactive compounds. The analyzes were performed using the R software (R Core Team, 2020).

\section{Results}

\subsection{Sensory characteristics}

With respect to taste, except for pure camu-camu jelly, all quality sensory attributes in all tested jellies showed values above $70 \%$ (Figure 1).

Looking at the appearance aspect, it can be noted that camu-camu jelly presented less acceptability when compared to the others. Higher acceptability was observed for appearance when it was mixed with other fruits, where the acceptability index showed average values close to $85 \%$.

As for color, all formulations presented good acceptability, with values close to $85 \%$. In terms of sensory attributes flavor and texture, pure camu-camu jelly presented the lowest acceptability. Although the material used to make the jellies is little known and underused in human nutrition, an acceptability index of over $70 \%$ was obtained for practically all formulations and attributes tested suggesting the possibility of commercialization of the formulated products.

When evaluating the purchase intention of camu-camu jellies, we observed a greater acceptance of mixed with other fruits formulations, with Camu-camu with Guava being the most

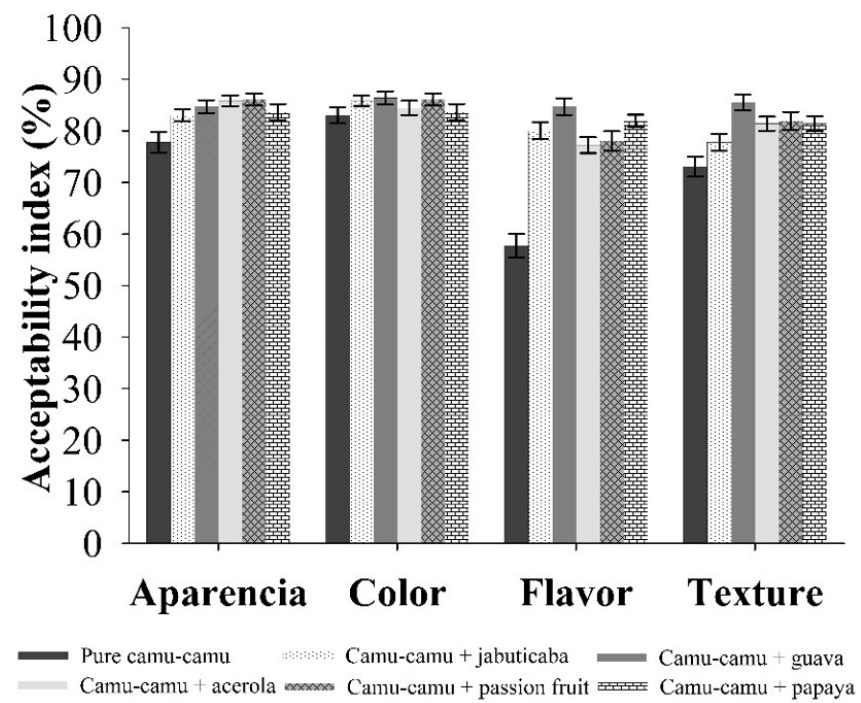

Figure 1. Acceptability index of pure and mixed with other fruits camu-camu jellies. Means + standard deviation $(n=40)$. 
preferred among the others, where more than $50 \%$ of tasters said they would definitely buy the product (Figure 2 ).

\subsection{Physical-chemical and nutraceutical quality}

When evaluating the average $\mathrm{pH}$ of the jellies we observed that the highest values were found in mixed jellies containing jabuticaba, guava and papaya. The lowest values were observed in pure and camu-camu jelly mixed with other fruits considered acidic, such as passion fruit and acerola, which, due to the higher acidity of its components, resulted in jellies with lower $\mathrm{pH}$ values (Table 1 ).

The soluble solids variable showed a statistically significant difference, with the highest average observed in camu-camu jelly with passion fruit. The lowest values of soluble solids were observed in pure camu-camu jelly and papaya mix. The titratable acidity was higher in passion fruit camu-camu jelly, followed by pure camu-camu jelly, a fact already expected, due to the large amount of organic acids present in these fruits ( $p>0.05)$. The jellies containing papaya, jabuticaba and guava showed the least acidic profiles.

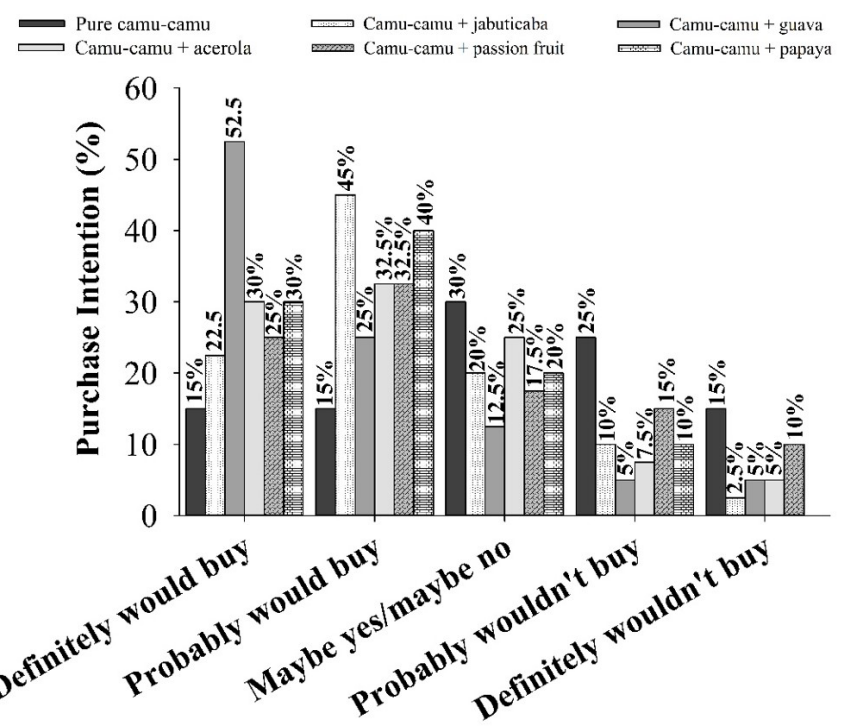

Figure 2. Purchase intention of pure and mixed camu-camu jellies with other fruits $(n=40)$.
Regarding the ratio variable, the highest values were observed in jellies containing less acidic fruits, such as guava, which differed from jabuticaba, papaya $(<0.05)$. The lowest values for the SS/ TA ratio were observed in passion fruit and pure camu-camu jellies, which differed statistically from each other $(p<0.05)$. This lower observed value is closely linked to the higher acidity of these jellies, denominator of the equation used as a flavor reference for fruits and jellies. The ascorbic acid content was higher in pure camu-camu jellies, followed by jabuticaba, papaya and acerola jellies that did not differ from each other ( $p>0.05)$, only from pure camu camu ( $\mathrm{p}<0.05)$. Which leads us to infer that the association of camu-camu with jabuticaba, papaya and acerola generates significant losses in the ascorbic acid content, improving the acceptability of the product.

When evaluating the total anthocyanin content of camucamu jellies, we observed that the camu-camu + jabuticaba, camu-camu + acerola jellies presented the highest amounts of this pigment (Table 2). Pure camu-camu jelly had the lowest amount of anthocyanins, indicating that the anthocyanins present in camu-camu are quite unstable when using heat treatment. Regarding flavonoids, pure camu-camu jelly showed a statistically higher mean value than the others $(p<0.05)$. This value was almost four times higher than camu-camu jelly with guava, which was the formulation with the lowest flavonoid content.

When quantifying the phenolic compounds, we observed higher average values for pure camu-camu jelly $(\mathrm{p}<0.05)$. The lowest values were detected in jellies with passion fruit, guava and papaya. When verifying the antioxidant activity of the jellies by both the DPPH method and the FRAP, we once again observed a higher antioxidant activity in pure camu-camu jelly, showing a statistically significant difference from all others $(\mathrm{p}<0.05)$. This data highlights the higher antioxidant capacity for pure camu-camu jelly therefore it can be considered as a good source of these compounds.

\subsection{Multivariate analysis}

Figure 3 shows the variation of the jelly formulations with the attributes of fruit quality, acceptability of products and purchase decision of the evaluators. The variability of the data was explained by $81.13 \%$ by the main components (PC). PC 1 and PC2 explained $59.55 \%$ and $21.58 \%$ of the data variability, respectively.

Table 1. $\mathrm{pH}$, soluble solids ( ${ }^{\circ}$ Brix), titratable acidity (mg of citric acid per $100 \mathrm{~g}^{-1}$ of sample), ratio and ascorbic acid (mg of ascorbic acid per $100 \mathrm{~g}^{-1}$ of sample) of different camu-camu and mixed jelly formulations with other fruits.

\begin{tabular}{|c|c|c|c|c|c|}
\hline Treatments & $\mathrm{pH}$ & Soluble solids & Titrable acidity & Ratio & Ascorbic acid \\
\hline Pure camu-camu & $3.02 \pm 0.01 \mathrm{c}$ & $67.17 \pm 0.34 \mathrm{~d}$ & $2.17 \pm 0.01 \mathrm{~b}$ & $30.98 \pm 0.12 \mathrm{~d}$ & $1726.63 \pm 16.49 \mathrm{a}$ \\
\hline Camu-camu+ jabuticaba & $3.16 \pm 0.03 \mathrm{a}$ & $69.30 \pm 0.26 c$ & $1.93 \pm 0.03 \mathrm{~d}$ & $35.92 \pm 0.75 b$ & $1467.63 \pm 42.07 b$ \\
\hline Camu-camu+ guava & $3.13 \pm 0.02 \mathrm{a}$ & $69.97 \pm 0.06 \mathrm{~b}$ & $1.86 \pm 0.01 \mathrm{de}$ & $37.69 \pm 0.29 \mathrm{a}$ & $1395.38 \pm 6.49 c$ \\
\hline Camu-camu+ acerola & $3.08 \pm 0.03 \mathrm{~b}$ & $69.77 \pm 0.21 b$ & $2.07 \pm 0.05 c$ & $33.72 \pm 0.75 c$ & $1456.42 \pm 18.51 \mathrm{~b}$ \\
\hline Camu-camu+ passion fruit & $3.07 \pm 0.02 \mathrm{bc}$ & $71.10 \pm 0.10 \mathrm{a}$ & $2.58 \pm 0.08 \mathrm{a}$ & $27.53 \pm 0.88 \mathrm{e}$ & $1297.78 \pm 24.06 \mathrm{~d}$ \\
\hline Camu-camu+ papaya & $3.15 \pm 0.04 \mathrm{a}$ & $66.67 \pm 0.06 \mathrm{~d}$ & $1.82 \pm 0.08 \mathrm{e}$ & $35.88 \pm 0.25 b$ & $1463.88 \pm 39.38 b$ \\
\hline Coefficient of variation-CV (\%) & 0.8 & 0.23 & 2.51 & 1.74 & 1.88 \\
\hline
\end{tabular}

Means followed by the same letter in the column do not differ from each other by lsd test $(\mathrm{p}<0.05)$. Means + standard deviation $(n=3)$ 
The variables that made the greatest contribution to CP 1 were: Flavor $(\mathrm{r}=0.97$; $\mathrm{p}<0.0001)$; appearance $(\mathrm{r}=0.89 ; \mathrm{p}<0.01)$; texture $(\mathrm{r}=0.89 ; \mathrm{p}<0.01)$; probably wouldn't buy $(\mathrm{r}=-0.85$; $\mathrm{p}<0.03)$; DPPH antioxidant $(\mathrm{r}=0.88$; $\mathrm{p}<0.01)$; maybe yes/ maybe no $(\mathrm{r}=-0.89 ; \mathrm{p}<0.01)$; ascorbic acid $(\mathrm{r}=-0.93 ; \mathrm{p}<0.005)$ and flavonoids $(\mathrm{r}=-0.98 ; \mathrm{p}<0.0004)$. In PC2, the variables TA $(\mathrm{r}=-0.96 ; \mathrm{p}<0.001)$ and Ratio $(\mathrm{r}=-0.86 ; \mathrm{p}<0.03)$ showed $\mathrm{a}$ high correlation, being more representative. The pure camucamu jelly and camu-camu jelly with guava were the ones that presented the greatest contributions to PC1, with $77.07 \%$ and $12.74 \%$ respectively. In PC2, the camu-camu jelly with passion

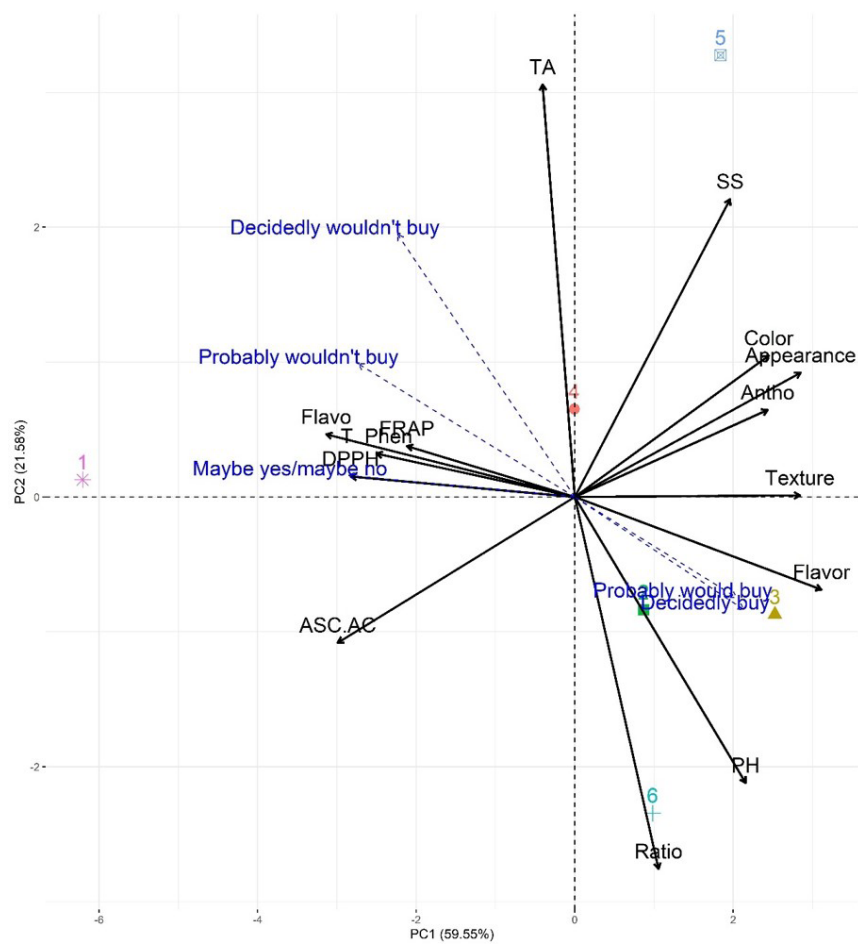

Figure 3. Principal component analysis (PC) performed on different jelly formulations and with the intention of purchasing products on sensory characteristics, organoleptic quality and bioactive compounds $(n=114)$. The pink asterisk symbol corresponds to formulation 1: (Pure camu-camu); the green square symbol, formulation 2: (Camu-camu with jabuticaba); the brown triangle symbol symbolizes formulation 3: (Camu-camu with Guava); the symbol in red circle symbolizes formulation 4: (Camu-camu with acerola); the blue open square symbol the formulation 5: (Camu-camu with passion fruit); and the light green (+) plus symbol for formulation 6: (Camu-camu with papaya). fruit and camu-camu jelly with papaya presented the largest contributions, with $59.17 \%$ and $30.33 \%$ respectively.

The attributes texture, flavor and Ratio were the variables that contributed to that consumers decided to buy the jellies produced in camu-camu jelly with guava. Consumers who would likely buy camu-camu with jabuticaba were induced by the $\mathrm{pH}$ and anthocyanin of the jellies tested. The pure camucamu jelly contributed to consumer uncertainty (maybe yes/ maybe no and probably wouldn't buy), occasionally because they have lower levels of quality attributes, as observed in the high negative correlations. However, it was the formulations that showed the highest levels of bioactive compounds and antioxidant activity (Figure 3 ).

The quality attribute of soluble solid fruits helps consumers to choose camu-camu jelly with passion fruit. The jellies of camu-camu jelly with papaya were preferred for their excellent organoleptic quality, since Ratio is an attribute that represents the quality index of a product. Formulations with lower levels of titratable acidity, flavonoids and vitamin $\mathrm{C}$ and high levels of Ratio and total phenolics contributed to consumers decidedly wouldn't buy popsicles (Figure 3).

\section{Discussion}

These results are possibly due to the pronounced taste of camu-camu (Peuckert et al., 2010), which suggest greater preference for jellies in formulations with other agricultural products, improving the taste of the product and increasing its acceptability above the recommended (Baú et al., 2010). As noted by (Araújo et al., 2014), when evaluating the combination of pepper jelly with acerola, observed that they obtained a good acceptance and purchase intention. The lowest acceptability index was probably affected by the high acidity present in camu-camu pulp (Akter et al., 2011; Barreto et al., 2013; Grigio et al., 2016, 2021) and, consequently, the products made from it.

The greater acceptance of the jelly due to its appearance and color is due to the consumer's first contact being the visual presentation with the product (Nascimento et al., 2020; Teixeira, 2009). Similarly, to the present study, Costa et al. (2020) the most selected samples of structured guava were those with the pinkish-red color attribute. It is worth mentioning that this color of guava is similar to that of camu-camu, making it an important visual aspect in the selection.

Table 2. Total anthocyanins ( $\mu \mathrm{g} \mathrm{g}^{-1}$ of sample), total flavonoids ( $\mu \mathrm{g} \mathrm{g}^{-1}$ of sample), phenolic compounds ( $\mu \mathrm{g} \mathrm{g}^{-1}$ of sample), and antioxidant activity by DPPH and FRAP ( $\mu \mathrm{g} \mathrm{g}^{-1}$ of sample) methods of different camu-camu and mixed with other fruits jelly formulations.

\begin{tabular}{lccccc}
\hline Treatments & Total anthocyanins & Total flavonoid & Phenolic compounds & $($ DPPH) & $($ FRAP) \\
\hline Pure camu-camu & $10.10 \pm 0.34 \mathrm{e}$ & $213.33 \pm 1.85 \mathrm{a}$ & $92.67 \pm 0.40 \mathrm{a}$ & $4.29 \pm 0.14 \mathrm{a}$ & $6.78 \pm 0.16 \mathrm{a}$ \\
Camu-camu+jabuticaba & $23.08 \pm 0.77 \mathrm{a}$ & $81.62 \pm 1.85 \mathrm{c}$ & $84.76 \pm 0.73 \mathrm{c}$ & $2.42 \pm 0.14 \mathrm{~cd}$ & $6.35 \pm 0.07 \mathrm{~b}$ \\
Camu-camu+guava & $18.83 \pm 0.89 \mathrm{c}$ & $52.04 \pm 1.85 \mathrm{e}$ & $75 \pm 0.33 \mathrm{~d}$ & $2.38 \pm 0.14 \mathrm{~d}$ & $6.28 \pm 0.06 \mathrm{~b}$ \\
Camu-camu+acerola & $23.08 \pm 0.77 \mathrm{a}$ & $88.15 \pm 0.93 \mathrm{~b}$ & $87.67 \pm 0.05 \mathrm{~b}$ & $3.73 \pm 0.18 \mathrm{~b}$ & $6.33 \pm 0.05 \mathrm{~b}$ \\
Camu-camu+passion fruit & $20.73 \pm 0.70 \mathrm{~b}$ & $86.30 \pm 0.93 \mathrm{~b}$ & $74.67 \pm 0.44 \mathrm{~d}$ & $2.38 \pm 0.05 \mathrm{~d}$ & $5.89 \pm 0.02 \mathrm{c}$ \\
Camu-camu+papaya & $16.64 \pm 0.17 \mathrm{~d}$ & $74.26 \pm 0.0 \mathrm{~d}$ & $72.15 \pm 0.21 \mathrm{e}$ & $2.69 \pm 0.28 \mathrm{c}$ & $5.55 \pm 0.05 \mathrm{~d}$ \\
Coefficient of variation-CV (\%) & 3.52 & 1.42 & 0.51 & 5.68 & 1.31 \\
\hline
\end{tabular}

Means followed by the same letter in the column do not differ from each other by lsd test $(\mathrm{p}<0.05)$. Means + standard deviation $(n=3)$. 
Sensory analysis is of paramount importance and is known to be effective in better understanding consumers' providing valid and reliable results of the products (Costa et al., 2020). Evaluation of the real intention to purchase the new product tested is considered very important factor for determining a possible commercialization.

The $\mathrm{pH}$ of the jellies in the present study remained below the data found in the literature (Caetano et al., 2012; Leão et al., 2012; Maciel et al., 2009), probably due to the large amount of acids present in the camu-camu pulp. According to Brazilian law (Brasil, 1978), based on Codex Alimentarius guidelines (Food and Agriculture Organization and World Health Organization), the jellies made in this study are classified as extra jellies, since they were prepared in practically the same proportion of fruit and sugar. Similar results were detected by (Maia et al., 2014) when working with extra tamarind jellies.

The average acidity values of the jellies tested in the present study are still higher than those reported in the literature (Grigio et al., 2019, 2021; Oliveira et al., 2014a, b; Santos et al., 2012; Viana et al., 2015). The average values observed in the present study are higher than those reported for rose apple (Syzygium jambos) jelly (Cardoso, 2008), probably due to the high acidity present in camu-camu.

Ascorbic acid is among the compounds that are considered important to human health, but is extremely sensitive to processing (Pereira et al., 2014). Higher values than those reported in the literature for acerola jelly were verified in the present study (Maciel et al., 2009), thus denoting the importance of adding camu-camu pulp to make jellies, in order to maintain in jellies desirable characteristics such as the amount of ascorbic acid throughout thermal processing.

The processing and manufacture of products lead to the deterioration of anthocyanins and their color, being mainly affected by the $\mathrm{pH}$, solvents, temperature, concentration and structure of anthocyanins, as well as the presence of oxygen, light, enzymes, and other substances contained in the plant (Schiozer \& Barata, 2007). Functional drinks have been developed with camu-camu and other fruits such as acerola, where anthocyanin instability in these products was reported as well (Dionisio et al., 2016; Maeda et al., 2007).

The peel of jabuticaba has been used to make jellies, as it is considered rich in flavonoids and serves as an alternative source of this phenolic compound (Dessimoni-Pinto et al., 2011). However, when comparing the mean values, we observed that camu-camu jelly provides about twice as many flavonoids as jabuticaba peel jelly. On the other hand, recent studies have shown the potential of using the lyophilized camu-camu peel as a source of enrichment for bioactive compounds (Grigio et al., 2021). This, due to the peel having richest phenolic profile, as well as anti-bacterial and anti-proliferative activities (Conceição et al., 2019).

Jellies are sugar rich products and it is normally expected that the bitter taste caused by phenolic compounds will be suppressed by the large amount of sugars (Pineli et al., 2015). However, this study shows the negative effect of the large amount of phenols on the taste of pure camu-camu jelly, thus causing a lower acceptance of this product. Possibly due to the high concentration of phenolic compounds and antioxidants present in the pure camu-camu jelly, it had a negative influence on the flavor. Because the high concentration of ascorbic acid, as well as other acids when concentrated in cooking, received a relatively low score from the tasters. This fact is evidenced by observing the correlation analysis, which shows a high negative correlation between the acceptability of the product with the levels of phenolic and antioxidant compounds. Similarly, when the pure pulp was used, there was a greater rejection of camu camu popsicle (Grigio et al., 2019, 2021). Therefore, there is a clear need to find fruit formulations that allow the maximum nutraceutical potential to be exploited and that obtain excellent consumer acceptance.

The antioxidant activity of fruits and jellies is directly related to the content of phenolic compounds (DessimoniPinto et al., 2011; Falcão et al., 2007).

Although the methodologies used are validated and the results are consistent, further complementary studies can be carried out aiming to identify groups of consumers in different cities due to the pattern of consumer acceptance vary in different regions (Nascimento et al., 2020).

\section{Conclusions}

The greatest preference was for mixed jams of camu-camu with guava and jabuticaba, in which they obtained greater acceptance and purchase intention. The characteristics of texture, flavor, anthocyanin, flavor, $\mathrm{pH}$ and ratio led the evaluators to probably and/or decidedly buy the products.

Jellies with higher levels of bioactive compounds and antioxitant activity obtained low acceptance and purchase intention, perhaps due to their high astringency.

\section{Acknowledgements}

The authors thank the Higher Education Personnel Improvement Coordination (CAPES) for their scholarships.

\section{References}

Akter, M. S., Oh, S., Eun, J. B., \& Ahmed, M. (2011). Nutritional compositions and health promoting phytochemicals of camu-camu (myrciaria dubia) fruit: a review. Food Research International, 44(7), 1728-1732. http://dx.doi.org/10.1016/j.foodres.2011.03.045.

Association of Official Analytical Chemists - AOAC. (2012). Official methods of analysis of AOAC International (19th ed.). Gaithersburg: AOAC International. Retrieved from http://www.eoma.aoac.org/

Araújo, E. R., Silva, P. K., Nascimento, M. F., Barral, M. A. A., Rêgo, M. M., \& Rêgo, E. R. (2014). Desenvolvimento de geleia de pimenta com acerola: análise sensorial e aceitação comercial. Revista Agropecuária Tecnica, 35, 81-88.

Azevêdo, J. C. S., Fujita, A., Oliveira, E. L., Genovese, M. I., \& Correia, R. T. P. (2014). Dried camu-camu (Myrciaria dubia H.B.K. McVaugh) industrial residue: a bioactive-rich Amazonian powder with functional attributes. Food Research International, 62, 934-940. http://dx.doi. org/10.1016/j.foodres.2014.05.018.

Azevêdo, J. C. S., Borges, K. C., Genovese, M. I., Correia, R. T. P., \& Vattem, D. A. (2015). Neuroprotective effects of dried camucamu (Myrciaria dubia HBK McVaugh) residue in C. elegans. Food 
Research International, 73, 135-141. http://dx.doi.org/10.1016/j. foodres.2015.02.015.

Barreto, A. G., Cabral, L. M. C., Matta, V. M., \& Freitas, S. P. (2013). Clarificação de polpa de camu-camu por microfiltração. Brazilian Journal of Food Technology, 16(3), 207-215. http://dx.doi.org/10.1590/ S1981-67232013005000026.

Bataglion, G. A., da Silva, F. M. A., Eberlin, M. N., \& Koolen, H. H. F. (2015). Determination of the phenolic composition from Brazilian tropical fruits by UHPLC-MS/MS. Food Chemistry, 180, 280-287. http://dx.doi.org/10.1016/j.foodchem.2015.02.059.

Baú, T. R., Alves da Cunha, M. A., Cella, S. M., Oliveira, A. L. J., \& Andrade, J. T. (2010). Barra alimentícia com elevado valor proteíco: formulação, caracterização e avaliação sensorial. Revista Brasileira de Tecnologia Agroindustrial, 4(1), 42-51. http://dx.doi. org/10.3895/S1981-36862010000100005.

Brand-Williams, W., Cuvelier, M. E., \& Berset, C. (1995). Use of a free radical method to evaluate antioxidant activity. LebensmittelWissenschaft + Technologie, 28(1), 25-30. http://dx.doi.org/10.1016/ S0023-6438(95)80008-5.

Brasil, Comissão Nacional de Normas e Padrões Para Alimentos CNNPA. (1978). Aprova normas técnicas especiais relativas a alimentos e bebidas (Resolução $\mathrm{n}^{\circ} 12$, de 12 de março de 1978). Diário Oficial [da] República Federativa do Brasil.

Caetano, P. K., Daiuto, É. R., \& Vieites, R. L. (2012). Característica físico-química e sensorial de geleia elaborada com polpa e suco de acerola. Brazilian Journal of Food Technology, 15(3), 191-197. http:// dx.doi.org/10.1590/S1981-67232012005000011.

Cardoso, R. L. (2008). Estabilidade da cor de geléia de jambo (Eugenia malaccensis, L.) sem casca armazenada aos $25^{\circ} \mathrm{CE} 35^{\circ} \mathrm{C}$ na presença e ausência de luz. Ciência e Agrotecnologia, 32(5), 1563. http://dx.doi. org/10.1590/S1413-70542008000500031.

Chagas, E. A., Lozano, R. M. B., Chagas, P. C., Bacelar-Lima, C. G., Garcia, M. I. R., Oliveira, J. V., Souza, O. M., Morais, B. S., \& Araújo, M. C. R. (2015). Intraspecific variability of camu-camu fruit in native populations of northern Amazonia. Crop Breeding and Applied Biotechnology, 15(4), 265-271. http://dx.doi.org/10.1590/1984-70332015v15n4a44.

Chirinos, R., Galarza, J., Betalleluz-Pallardel, I., Pedreschi, R., \& Campos, D. (2010). Antioxidant compounds and antioxidant capacity of Peruvian camu camu (Myrciaria dubia (H.B.K.) McVaugh) fruit at different maturity stages. Food Chemistry, 120(4), 1019-1024. http:// dx.doi.org/10.1016/j.foodchem.2009.11.041.

Conceição, N., Albuquerque, B. R., Pereira, C., Corrêa, R. C. G., Lopes, C. B., Calhelha, R. C., Alves, M. J., Barros, L., \& Ferreira, I. C. F. R. (2019). By-products of Camu-Camu [Myrciaria dubia (Kunth) McVaugh] as promising sources of bioactive high added-value food ingredients: functionalization of yogurts. Molecules, 25(1), 70. http:// dx.doi.org/10.3390/molecules25010070. PMid:31878221.

Costa, J. N., Brito, S. A., Leal, A. R., Rodrigues, D. C., Nascimento, L. G. L., Figueiredo, R. W., Mata, P., \& Sousa, P. H. M. (2020). Sensory characteristics of structured guava (Psidium guajava): comparison of optimized descriptive profile, cata and sensory acceptance methods. Food Science and Technology, 40(Suppl. 2), 496-502. http://dx.doi. org/10.1590/fst.25819.

Delgado-Nieblas, C. I., Zazueta-Morales, J. J., Aguilar-Palazuelos, E., Jacobo-Valenzuela, N., Aguirre-Tostado, F. S., Carrillo-López, A., RuizArmenta, X. A., \& Telis-Romero, J. (2018). Physical, microstructural and sensory characteristics of extruded and microwave-expanded snacks added with dehydrated squash. Revista Mexicana de Ingeniería Química, 17(3), 805-821. http://dx.doi.org/10.24275/uam/izt/dcbi/ revmexingquim/2018v17n3/Delgado.
Dessimoni-Pinto, N. A. V., Moreira, W. A., Cardoso, L. M., \& Pantoja, L. A. (2011). Aproveitamento tecnológico da casca de jabuticaba para elaboração de geléia. Food Science and Technology, 31(4), 864-869. http://dx.doi.org/10.1590/S0101-20612011000400006.

Dionisio, A. P., Wurlitzer, N. J., Goes, T de S., Borges, M. F., Garruti, D., \& Araújo, I. M. S. (2016). Estabilidade de uma bebida funcional de frutas tropicais e yacon (Smallanthus sonchifolius) durante o armazenamento sob refrigeração. Archivos Latinoamericanos de Nutricion, 66, 148-155. Retrieved from http://ve.scielo.org/pdf/ alan/v66n2/art08.pdf

Dutcosky, S. D. (1996). Análise sensorial de alimentos. Curitiba: Champagnat.

Falcão, A. P., Chaves, E. S., Kuskoski, E. M., Fett, R., Falcão, L. D., \& Bordignon-Luiz, M. T. (2007). Índice de polifenóis, antocianinas totais e atividade antioxidante de um sistema modelo de geléia de uvas. Food Science and Technology, 27(3), 637-642. http://dx.doi. org/10.1590/S0101-20612007000300032.

Ferreira, R. M. A., Aroucha, E. M. M., Góis, V. A., Silva, D. K., \& Sousa, C. M. G. (2011). Qualidade sensorial de geléia mista de melancia e tamarindo. Revista Caatinga, 24(2), 202-206. Retrieved from https:// periodicos.ufersa.edu.br/index.php/caatinga/article/view/1706/4733

Fidelis, M., Moura, C., Kabbas, T. Jr., Pap, N., Mattila, P., Mäkinen, S., Putnik, P., Bursać Kovačević, D., Tian, Y., Yang, B., \& Granato, D. (2019). Fruit seeds as sources of bioactive compounds: sustainable production of high value-added ingredients from by-products within circular economy. Molecules, 24(21), 3854. http://dx.doi. org/10.3390/molecules24213854. PMid:31731548.

Fracassetti, D., Costa, C., Moulay, L., \& Tomás-Barberán, F. A. (2013). Ellagic acid derivatives, ellagitannins, proanthocyanidins and other phenolics, vitamin $\mathrm{C}$ and antioxidant capacity of two powder products from camu-camu fruit (Myrciaria dubia). Food Chemistry, 139(14), 578-588. http://dx.doi.org/10.1016/j.foodchem.2013.01.121. PMid:23561148.

Fujita, A., Sarkar, D., Wu, S., Kennelly, E., Shetty, K., \& Genovese, M. I. (2015). Evaluation of phenolic-linked bioactives of camucamu (Myrciaria dubia Mc. Vaugh) for antihyperglycemia, antihypertension, antimicrobial properties and cellular rejuvenation. Food Research International, 77, 194-203. http://dx.doi.org/10.1016/j. foodres.2015.07.009.

Grigio, M. L., Chagas, E. A., Berlingieri Durigan, M. F., Andrade Sousa, A., Mota Filho, A. B., \& Chagas, P. C. (2016). Determination of harvest time and quality of native camu-camu fruits (Myrciaria dubia (Kunth) Mc Vaugh) during storage. Fruits, 71(6), 373-378. http://dx.doi.org/10.1051/fruits/2016029.

Grigio, M. L., Durigan, M. F. B., \& Chagas, E. A. (2019). Different formulations of camu-camu popsicle: characterization, vitamin C and sensorial analysis of an opportunity to family agroindustry. Food Science and Technology, 39(Suppl. 1), 93-97. http://dx.doi. org/10.1590/fst.38417.

Grigio, M. L., Moura, E. A., Carvalho, G. F., Zanchetta, J. J., Chagas, P. C., Chagas, E. A., \& Durigan, M. F. B. (2021). Nutraceutical potential, qualitative and acceptability of different camu-camu popsicle. Journal of Food Processing and Preservation, 45(3), e15305. http://dx.doi. org/10.1111/jfpp.15305.

Leão, K. M. M., Boudou, F. S. T., Castro, A. A., \& Figueiredo, A. V. D. (2012). Formulação e avaliação físico-quimica de geleia de mamão (Carica papaya L.). Scientia Plena, 8(3), 1-3. Retrieved from www. scientiaplena.org.br

Lees, D. H., \& Francis, F. J. (1972). Standardization of pigment analyses in cranberries. HortScience, 7(1), 83-84. 
Maciel, M. I. S., Melo, E. D. A., Lima, V. L. A. G., Silva, W. S. D., Maranhão, C. M. C., \& Souza, K. A. (2009). Características sensoriais e físico-químicas de geleias mistas de manga e acerola. Boletim do Centro de Pesquisa e Processamento de Alimentos, 27(2), 247-256. http://dx.doi.org/10.5380/cep.v27i2.22035.

Maeda, R. N., Pantoja, L., Yuyama, L. K. O., \& Chaar, J. M. (2007). Estabilidade de ácido ascórbico e antocianinas em néctar de camu-camu (Myrciaria dubia (H. B. K.) McVaugh). Food Science and Technology, 27(2), 313-316. http://dx.doi.org/10.1590/S0101-20612007000200018.

Maia, J. D., Travália, B. M., Andrade, T. A., Silva, G. K. C., Andrade, J. K. S., Oliveira, A. M. Jr., \& Moreira, J. J. S. (2014). Development, physical-chemycal, microbyological and sensory analises of tamarind jam. Revista Gestão, Inovação e Tecnologias, 4(1), 632-641.

Nascimento, R. Q., Tavares, P. P. L. G., Meireles, S., Anjos, E. A., Andrade, R. B., Machado, B. A. S., Souza, A. L. C., \& Mamede, M. E. O. (2020), Study on the sensory acceptance and check all that apply of mixed juices in distinct brazilian regions. Food Science and Technology, 40(Suppl. 2), 708-717. http://dx.doi.org/10.1590/fst.37619.

Neves, L. C., Silva, V. X., Pontis, J. A., Flach, A., \& Roberto, S. R. (2015). Bioactive compounds and antioxidant activity in preharvest camu-camu [Myrciaria dubia (H.B.K.) Mc Vaugh] fruits. Scientia Horticulturae, 186, 223-229. http://dx.doi.org/10.1016/j. scienta.2015.02.031.

Oliveira, E. N. C., Santos, D. C., Rocha, A. P. T., Gomes, J. P., \& Silva, W. P. (2014a). Estabilidade de geleias convencionais de umbu-cajá durante $\mathrm{o}$ armazenamento em condições ambientais. Revista Brasileira de Engenharia Agrícola e Ambiental, 18(3), 329-337. http://dx.doi. org/10.1590/S1415-43662014000300013.

Oliveira, E. N. A., Santos, D. C., Rocha, A. P. T., \& Gomes, J. P. (2014b). Desenvolvimento, caracterização e estabilidade de geleia tradicional de umbu-cajá. Revista Brasileira de Fruticultura, 36(3), 628-639. http://dx.doi.org/10.1590/0100-2945-366/13.

Pereira, H. L., Silva, S. P., Santos, T. A., Oliveira, L. F., \& Oliveira, I. P. (2014). Produção de geléia mista "geleado". Revista Faculdade Montes Belos, 7(4), 130-153. Retrieved from http://www.fmb.edu. br/revistaFmb/index.php/fmb/article/view/148/142

Peuckert, Y., Viera, V., Hecktheuer, L., Marques, C. T., \& Rosa, C. S. (2010). Caracterização e aceitabilidade de barras de cereais adicionadas de proteína texturizada de soja e camu - camu (Myrciaria dúbia). Alimentos e Nutrição, 21, 147-152.

Pineli, L. L. O., Moretti, C. L., Chiarello, M., \& Melo, L. (2015). Influence of strawberry jam color and phenolic compounds on acceptance during storage. Revista Ceres, 62(3), 233-240. http:// dx.doi.org/10.1590/0034-737X201562030002.
R Core Team. (2020) R: a language and environment for statistical computing. Vienna: R Foundation for Statistical Computing. Retrieved from https://www.r-project.org/

Ranganna, S. (1986) Handbook of analysis and quality control for fruit and vegetable products (2nd ed.). New Delhi: Tata McGraw-Hill.

Rufino, M. S. M., Alves, R. E., Brito, E. S., Morais, S. M., Sampaio, C. G., Pérez-Jiménez, J., \& Saura-Calixto, F. D. (2006). Metodologia científica: determinação da atividade antioxidante total em frutas pelo método de redução do ferro (FRAP) (Comunicado Técnico, No. 4). Fortaleza: Embrapa Agroindústria Tropical. Retrieved from https:// ainfo.cnptia.embrapa.br/digital/bitstream/CNPAT-2010/11964/1/ cot-125.pdf

Santos, P. R. G., Cardoso, L. M., Bedetti, S. F., Hamacek, F. R., Moreira, A. V. B., Martino, H. S. D., Pinheiro-Sant'Ana, H. M. (2012). Geleia de cagaita (Eugenia dysenterica DC.): desenvolvimento, caracterização microbiológica, sensorial, química e estudo da estabilidade. Revista do Instituto Adolfo Lutz, 71(2), 281-290.

Schiozer, A. L., \& Barata, L. E. S. (2007). Estabilidade de corantes e pigmentos de origem vegetal. Revista Fitos, 3, 6-24.

Singleton, V. L., Orthofer, R., \& Lamuela-Raventós, R. M. (1999). Analysis of total phenols and other oxidation substrates and antioxidants by means of folin-ciocalteu reagent. Methods in Enzymology, 299, 152178. http://dx.doi.org/10.1016/S0076-6879(99)99017-1.

Teixeira, L. V. (2009). Análise sensorial na indústria de alimentos. Revista do Instituto de Latícinios Cândido Tostes, 64, 12-21.

Viana, E. S., Jesus, J. L., Reis, R. C., Fonseca, M. D., \& Sacramento, C. K. (2012). Caracterização fisico-química e sensorial de geleia de mamão com araçá-boi. Revista Brasileira de Fruticultura, 34(4), 1154-1164. http://dx.doi.org/10.1590/ S0100-29452012000400024.

Viana, E. S., Mamede, M. E. O., Reis, R. C., Carvalho, L. D. D., \& Fonseca, M. D. (2015). Desenvolvimento de geleia de umbu-cajá convencional e dietética. Revista Brasileira de Fruticultura, 37(3), 708-717. http:// dx.doi.org/10.1590/0100-2945-018/14.

Yahia, E. M. (2009). The contribution of fruit and vegetable consumption to human health. In L. De la Rosa, E. AlvarezParrilla \& G. A. Gonzalez-Aguilar (Eds.), Fruit and vegetable phytochemicals (pp. 3-51). Oxford: Wiley-Blackwell. http://dx.doi. org/10.1002/9780813809397.ch1.

Zhishen, J., Mengcheng, T., \& Jianming, W. (1999). The determination of flavonoid contents in mulberry and their scavenging effects on superoxide radicals. Food Chemistry, 64(4), 555-559. http://dx.doi. org/10.1016/S0308-8146(98)00102-2. 